The University of Maine

\title{
DigitalCommons@UMaine
}

Earth Science Faculty Scholarship

Earth Sciences

1985

\section{A Preliminary Assessment of the Potential Application of Glaciochemical Investigations on Heard Island, South Indian Ocean}

\author{
MaryJo Spencer \\ Paul Andrew Mayewski \\ University of Maine, paul.mayewski@maine.edu \\ William Berry Lyons \\ Martin R. Hendy
}

Follow this and additional works at: https://digitalcommons.library.umaine.edu/ers_facpub

Part of the Geochemistry Commons, Glaciology Commons, and the Hydrology Commons

\section{Repository Citation}

Spencer, Mary Jo; Mayewski, Paul Andrew; Lyons, William Berry; and Hendy, Martin R., "A Preliminary Assessment of the Potential Application of Glaciochemical Investigations on Heard Island, South Indian Ocean" (1985). Earth Science Faculty Scholarship. 221.

https://digitalcommons.library.umaine.edu/ers_facpub/221 


\title{
A PRELIMINARY ASSESSMENT OF THE POTENTIAL APPLICATION OF GLACIOCHEMICAL INVESTIGATIONS ON HEARD ISLAND, SOUTH INDIAN OCEAN
}

\author{
By Mary Jo SPencer, Paul A. MAyewski, WM. BerRy LyONS, \\ (Glacier Research Group and Department of Earth Sciences, University of New Hampshire, Durham, \\ New Hampshire 03824, U.S.A.) \\ and MARTIN R. HENDY \\ (Glaciology Section, Department of Earth Sciences, University of Melbourne, Victoria 3052, Australia)
}

\begin{abstract}
Aвstzuct. Analyses of fluoride, chloride, sodium, sulfate, bromide, nitrate, and iron from a $3 \mathrm{~m}$ snow pit on Heard Island, collected at an elevation of 2450 , m are used to assess the potential of glaciochemical studies on.. Heard Island glaciers. Sources for the chemical species are identified and, in particular, chloride, sodium, and sulfate are found to be useful seasonal indicators. The total record measured is believed to be less than one mass-balance year.
\end{abstract}

REsunge. Une estimation preliminaire des applications posentielles des mesures glaciochimiques dans l'Heard Island, au Sud de l'Océan Indien. On a utilisé des analyses de fluorures, chlorures, sodium, sulfates, bromures, nitrates et fer effectuées dans un carrotage de neige dans Heard Island prélevé une altitude de $2450 \mathrm{~m}$, en vue d'évaluer les possibilités des études glaciochimiques sur les glaciers de

\section{INTRODUCTION}

Studies of the chemical species concentrations and the hydrologic balance on remote islands in the Southern Ocean, although valuable in understanding atmospheric circulation in this vast region, have only been undertaken in a limited fashion due largely to site accessibility. We present results of a pilot study of the chemical species concentrations found in $3 \mathrm{~m}$ deep snow pit excavated on the side of Big Ben (2450 m a.s.l.) close to the top of Heard Island.

As noted by Allison (1980), Heard Island (lat. $53^{\circ} 05^{\prime} \mathrm{S}$., long. $73^{\circ} 30^{\prime} \mathrm{E}$.) is a $44 \mathrm{~km}$ by $19 \mathrm{~km}$ island located south of the Antarctic Convergence. The morphology of the island is largely dominated by its active volcano, Big Ben, and the island is $80 \%$ covered by snow and ice with in several cases glaciers extending down to sea-level. Recent glacier fluctuations on the island reveal a period of recession during 1947-63 followed by re-advance of several (Budd, 1964, 1970; Budd and Stephenson, 1970), which, basod on the 100 years residence time for ice in these relatively thin, fast-flowing glaciers, implies that they are highly responsive to recent changes in climate (Lambeth, 1951; Allison, 1980). It is this responsiveness which has prompted considerable interest in the island's hydrologic mass balance (Allison, 1980) and in the assessment of proxy indicators for assessing climatic change, hence our pilot study.

Climatically, Heard Island is of considerable interest because of its remote location and its location in a latitudinal belt of intenso ventilation and precipitation (Radok and Watts, 1975). Basod on the period 1949-64, as many as $80-96$ depressions annually pass over Heard Island, and 13-48\% of these come from the north (Radok and Watts, 1975). Estimates of the climatic regime at $2400 \mathrm{~m}$, as made by Allison (1980) using relations from Budd and Allison (1975), suggest that, based on theoretical considerations, precipitation at this level is $4.2 \mathrm{~m} \mathrm{a}^{-1}$ water
Heard Island. On a identifié les sources des différents corps chimiques, en particulier les chlorures, le sodium et les sulfates se sont montrés de bons indicateurs de saison. L'ensemble de la tranche de neige analysée ne dépasse pas, croit-on, une accumulation annuelle.

Zusumagno Assung. Eine vorläufige Einschätzung der moglichen Anwendung glazialchemischer Untersuchungen auf Heard Island, Süd-Indischer Ozean. Analysen des Fluorid-, Chlorid-, Sodium-, Sulfat-, Bromid-, Nitrat- und Eisengehaltes aus einem $3 \mathrm{~m}$ tiefen Schneeschacht in 2450 $m$ Hohe auf Heard Island werden zur Einschătzung der Leistungsfahigkeit glazialchemischer Studien an den Gletschern der Insel herangezogen. Die Quellen for die chemischen Bestandteile werden festgestellt; speziell erweisen sich Chlorid, Sodium und Sulfat als nutzliche jahreszeitliche Indikatoren. Es wird vermutet, dass die untersuchte Schicht weniger als ein Massenbilanzjahr erfassen.

equivalent and ablation is zero. Thus, it is estimated that little to no melt is present at the $2450 \mathrm{~m}$ sampling site used in this study. The lack of melt at the study-site elevation is substantiated by the lack of ice lenses in the $3 \mathrm{~m}$ study pit and a relatively low ${ }^{18} \mathrm{O}$ value of $-12 \%$ measured on snow samples from this site.

\section{DATA COLLECTION}

Samples collected for this study come from a vertical wall in a bergschrund on the flank of Big Ben $(2450 \mathrm{~m})$ and were collected in March 1983. The wall was excavated at least $20 \mathrm{~cm}$ horizontally -using pre-cleaned Plexiglass scrapers. The collector wore non-particulating garments, a particle mask, and polyethylene gloves during all aspects of the sampling operation. Samples for anions and sodium, collected in soap-and-water pre-cleaned bottles and for iron in acid-washed bottles, were recovered at $10 \mathrm{~cm}$ intervals to a depth of $300 \mathrm{~cm}$. Additional sample bottles were maintained for blank studies. Details of pre-cleaning of sample containers and sampling equipment have been given by Mayewski and others (1984).

\section{ANALYTICAL METHODOLOGY}

Anion analyses were performed by ion chromatography using D Dionex Model 2010 ion chromatograph with an AS-4 column. The eluent used was a $0.021 \mathrm{~mol} \mathrm{l}^{-1}$ $\mathrm{NaHCO}_{3} / 0.0169 \mathrm{~mol} \mathrm{l}^{-1} \mathrm{Na}_{2} \mathrm{CO}_{3}$ solution. A 100 -fold eluent salt concentrate was used to spike the samples in order to eliminate the water dip. The ratio of spike volume to sample volume was $1: 100$. The sample loop used had a volume of $0.2 \mathrm{ml}$. A peristaltic pump was used to draw the samples through Teflon tubing into the sample loop. Prior to injection, the loop was rinsed with $4 \mathrm{ml}$ of sample. Between samples the sample loop was rinsed with Milli-Q 
water. Each sample was analyzed twice. The average precision was $5 \%$ for fluoride, $1 \%$ for chloride, $3 \%$ for nitrate, $3 \%$ for bromide, and $1 \%$ for sulfate. Extra sample bottles were filled with Milli- $Q$ water and analyzed to serve as container and methodology blanks. Blank values were $0.14 \pm 0.08 \mu \mathrm{mol} 1^{-1}$ for chloride, $0.29 \pm 0.16 \mu \mathrm{mol} \mathrm{l^{-1 }}$ for sulfate, and below detection for the remaining anions. The detection limits were approximately $0.02 \mu \mathrm{mol} \mathbf{1}^{-1}$ for fluoride, $0.02 \mu \mathrm{mol} \mathrm{I}^{-1}$ for chloride, $0.02 \mu \mathrm{mol} \mathrm{l}^{-1}$ for nitrate, $0.03 \mu \mathrm{mol} \mathrm{^{-1 }}$ for bromide, and $0.02 \mu \mathrm{mol} 1^{-1}$ for sulfate.

The iron samples were acidified with Ultrex $\mathrm{HNO}_{3}$ (J.T. Baker) to $1 \%$ vol./vol., and were analyzed by graphitefurnace atomic absorption spectrometry. A Perkin Elmer Model 2280 spectrometer equipped with a Model 400 furnace was used for these analyses. The injection volume was $50 \mathrm{\mu l}$. The char temperature was $1000^{\circ} \mathrm{C}$ and an atomization temperature of $2500^{\circ} \mathrm{C}$ was used. The average iron concentration for the blanks was $0.05 \mu \mathrm{mol} \mathrm{l}^{-1}$ and the precision was $5 \%$.

Sea-salt corrections were made for sulfate and bromide based on sodium. The molar ratios used for sea salt were 0.0602 for $\mathrm{SO}_{4}$ and 0.00180 for $\mathrm{Br}$.

\section{DATA PRESENTATION AND DISCUSSION}

Data are presented in the following order: fluoride, chloride, sodium, sulfate, bromide, nitrate, and iron. Discussion includes distribution with depth, potential sources, and comparison with data from similar geographic localities. This is followed by discussion of seasonal signals and a glaciochemically derived estimate of mass balance.

Fluoride concentrations (Fig. 1) display no particular trend with depth as might be expected due to the island's volcano, Big Ben, which no doubt supplies sporadic injections of this chemical species. Fluoride ranges from 0.3 to $3.9 \mu \mathrm{mol} \mathrm{l}^{-1}$ with a mean of $1.6 \mu \mathrm{mol} \mathrm{l}^{-1}$. This is similar to the $1.3 \mu \mathrm{mol} \mathrm{I}^{-1}$ concentration measured in Hawaiian precipitation (Harding and Miller, 1982). Similarities in geographic location and proximity to volcanic sources of both sites explain the correspondence in concentrations.

Chloride concentrations (Fig. 1) display two maxima $(0-120 \mathrm{~cm}$ and $220-300 \mathrm{~cm})$ and one minimum (120-220 $\mathrm{cm})$. The range in concentration is $1.7-105 \mu \mathrm{mol} \mathrm{l}^{-1}$, which is in the range of chloride values measured for precipitation from Hawaii, means 20.9 and $5.92 \mu \mathrm{mol} \mathrm{l}^{-1}$ (Duce and others, 1965; Harding and Miller, 1982, respectively), from Bermuda (Church and others, 1982), mean 191 umol $1^{-1}$, from Ile Amsterdam (Galloway and others, 1982), range 12.6-1480 $\mu \mathrm{mol} \mathrm{l}^{-1}$, mean $406 \mu \mathrm{mol} \mathrm{l}^{-1}$, and from James Ross Island, West Antarctica (Aristarain and others, 1982), range $6.1-36.9 \mu \mathrm{mol} \mathrm{l}^{-1}$. The primary source for the chloride at these sites is marine, although in the case of Heard Island there could be volcanic inputs. The high range in concentrations for sites such as Heard Island, Ile Amsterdam, and James Ross Island, is caused by seasonal changes in the extent of sea ice surrounding these sites and/or long transport of air masses to these islands. The higher chloride concentrations measured on Ile Amsterdam compared to Heard Island reflect the fact that Ile Amsterdam is farther from Antarctic sea ice than Heard Island and/or differences in sample-site elevation, 0 to 2450 $\mathrm{m}$, respectively. Herron (1982[b]) noted decreases in chloride concentration with elevation in Antarctica and Greenland.

Sodium concentrations (Fig. 1) reach maxima and minima at the same depths as chloride, as reflected by a correlation coefficient of $r=0.93$. Sodium ranges in concentration from 1.9 to $50.4 \mu \mathrm{mol} \mathrm{I}^{-1}$ with a mean of 17.5 $\mu \mathrm{mol} \mathrm{l}^{-1}$. Values for Bermuda (Church and others, 1982) have a mean of $148 \mu \mathrm{mol} \mathrm{^{-1 }}$, Ile Amsterdam (Galloway and others, 1982) a mean of $334 \mu \mathrm{mol} 1^{-1}$, and James Ross Island (Aristarain and others, 1982) in the range 0.8-4.1 $\mu \mathrm{mol} \mathrm{l}^{-1}$. Although most of the Heard Island sodium is believed to be marine-derived, almost all chloride to sodium ratios with depth are enriched at least slightly with sodium, suggestive of either a crustal input of sodium or a decline in chloride concentration relative to sodium with elevation. The chloride to sodium ratios increase to near sea-water ratios in the bottom section of the core with depth, also suggesting that volcanically derived chloride is probably not present in the snow pit.

Sulfate concentrations (Fig. 1) follow maxima and minima similar to those of chloride and sodium, correlation coefficients of $r=0.93$ and $r=0.88$, respectively. The range in concentration of sulfate is $<0.16-4.5 \mu \mathrm{mol} \mathrm{^{-1 }}$ with a mean of $1.2 \mu \mathrm{mol} \mathrm{I}^{-1}$. Values for Hawaii (Harding and Miller, 1982) are a mean of $9 \mu \mathrm{mol} \mathrm{l}^{-1}$, for Bermuda (Church and others, 1982) a mean of $18 \mu \mathrm{mol} \mathrm{l^{-1 }}$, for Ile Amsterdam (Galloway and others, 1982) a range of 3.7-75 $\mu \mathrm{mol} \mathrm{I}^{-1}$ with a mean of $26.3 \mu \mathrm{mol} \mathrm{^{-1 }}$, and for James Ross Island (Aristarain and others, 1982) a mean of $3.0 \mu \mathrm{mol} 1^{-1}$. The close correlation with depth of sulfate, chloride, and sodium suggests that most of the sulfate signal is marine, hence mean values are similar to other seasonally iceaffected areas such as James Ross Island. Non-sea-salt sulfate accounts for peaks at $30-40,80-100,180$, and $230 \mathrm{~cm}$. This non-sea-salt sulfate could be from biogenic, volcanic, and/or anthropogenic sources. The location of the study site probably reduces the importance of anthropogenic inputs. Non-sea-salt sulfate compared to chloride with depth has a low correlation coefficient, $r=0.49$, suggesting only a minor association, therefore, favoring a volcanic source for this non-sea-salt sulfate.

Bromide concentrations (Fig. 1) have several maxima with depth $(90,170,230$, and $260 \mathrm{~cm})$. They range from $<0.03$ to $0.20 \mu \mathrm{mol} 1^{-1}$ with a mean of $0.05 \mu \mathrm{mol} \mathrm{1^{-1 }}$. Bromide concentrations in Hawaii (Harding and Miller, 1982) are similar and have a mean of $0.3 \mu \mathrm{mol} \mathrm{^{-1 }}$. The latter are due primarily to marine input. However, on Heard Island, bromide could be derived from both marine and volcanic sources. Subtraction of the marine component of the bromide, ratioed to sodium, leaves maxima as before. If these maxima are volcanic, they do not have obvious correlative maxima in other volcanic indicators from this study, such as fluoride or non-sea-salt sulfate. However, as noted by Herron (1982[b]), volcanic emissions of different chemical species recorded in ice cores may not all be displayed at the same stratigraphic level due to differences in the type and timing of the chemical species in the emissions. Brominated organic gases have been observed in the Arctic atmosphere (Berg and others, 1984). Therefore, it is possible that the excess bromide may be from an oceanic biogenic source.

Nitrate concentrations (Fig. 1) reach a maximum of 1.7 mol $\mathrm{l}^{-1}$ at $20-40 \mathrm{~cm}$ depth and remain relatively low, no higher than $0.5 \mu \mathrm{mol} \mathrm{I}^{-1}$ at all other depths. Values for Hawaii (Harding and Miller, 1982) have a mean of 0.6 $\mu \mathrm{mol} \mathrm{1^{-1 }}$, Bermuda (Church and others, 1982) a mean of 6.6 umol $1^{-1}$, and Ile Amsterdam (Galloway and others, 1982) a range of $0.3-8.7 \mu \mathrm{mol} \mathrm{I}^{-1}$. Sources for nitrate in remote precipitation are numerous (Lyons and Mayewski, 1983) The range in these values may represent the background atmosphere. The peak in nitrate at $20-40 \mathrm{~cm}$ depth will be discussed in a later section of this paper.

Iron ranges from 0.02 to $0.4 \mu \mathrm{mol} \mathrm{l}^{-1}$ (Fig. 1) with a mean of $0.1 \mu \mathrm{mol} 1^{-1}$. Crustal weathering is the presumed primary source of iron in this region. Little iron data are available for comparison except for values from southern Victoria Land, Antarctica (Mayewski and Lyons, 1982), range $0.4-4.8 \mu \mathrm{mol} 1^{-1}$. The considerably larger area of exposed terrain in the latter area, and hence larger crustal weathering source, may explain the disparity in concentrations. The lower concentration on Heard Island may represent the "background" marine atmosphere for iron. Since iron is transported as a particle, it is probable that any microparticle signal retrieved from Heard Island would be as weak as the iron signal with depth.

The close correspondence between the concentration profiles with depth for the chemical species chloride, sodium, and sulfate is, no doubt, intimately tied to their common marine source. The period of minimum marine influence is probably prompted by the presence of continuous Antarctic sea ice to within, during at least some years, several tens of miles of Heard Island, as inferred from Antarctic sea-ice distributions for the period 1973-76 (Zwally and others, 1983), and the maximum marine influence would be during the period of minimum sea-ice extent. 

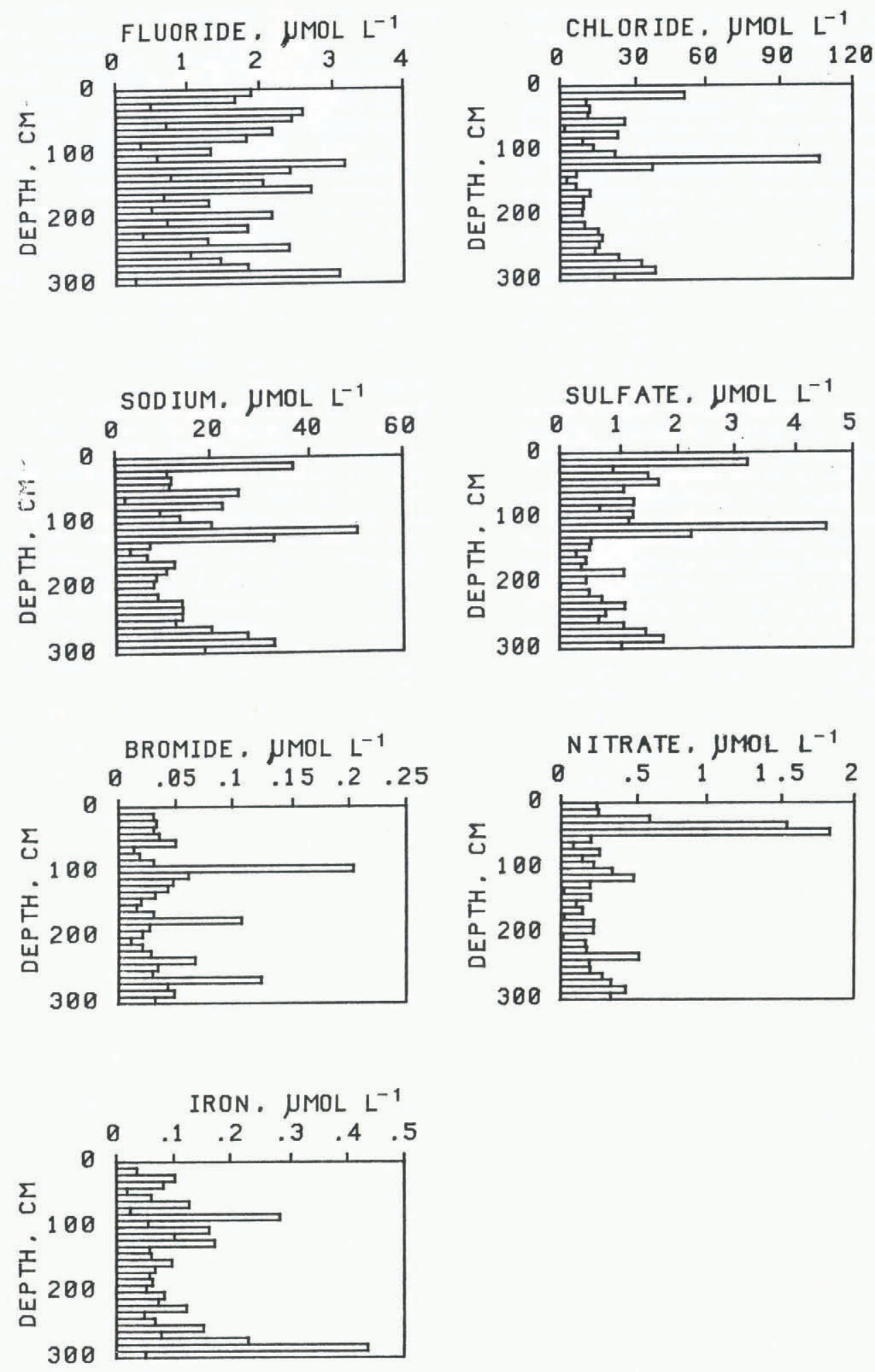

Fig. 1. Concentration of fluoride, chloride, sodium, sulfate, bromide, nitrate, and iron with depth.

Although the theoretically estimated mass balance close to the elevation of the sample site is $4.2 \mathrm{~m} \mathrm{a}^{-1}$, we estimate, using marine-chemistry indicators, that the $3.0 \mathrm{~m}$ snow pit in this study may represent close to a year of accumulation. We base this assumption not only on what we feel are seasonal signals in marine indicators but also on independent meteorological information. As noted by Radok and Watts (1975), greater than mean precipitation characterized the period December-May for most of the observation period 1948-54 on Heard Island. If these months are usually a period of relatively high precipitation for the year, then precipitation values from this period are, of course, useful in estimating yearly precipitation. Allison (1980) recorded a total precipitation of $13.24 \mathrm{~cm}$ for the period 27 January-8 March 1971 at Atlas Cove on the coast of Heard Island. This relatively low precipitation for a relatively wet time of the year could translate, particularly at an elevation of 2450 $\mathrm{m}$, into a mass balance significantly less than $4.2 \mathrm{~m} \mathrm{a}^{-1}$. Based on the knowledge that the surface of the snow pit is approximately early fall, the maxima in marine chemical species at $0-120 \mathrm{~cm}$ may represent some part of spring to early fall, the minima in marine input at $120-220 \mathrm{~cm}$ may represent perhaps late fall or early winter to early spring, while the marine maxima from 220 to $300 \mathrm{~cm}$ may be part of the spring to fall sequence. As defined by Radok and Watts (1975), based on an evaluation of monthly surface 
temperatures from Atlas Cove, the Heard Island seasons are as follows: summer (December-April), fall (May), winter (June-October), and spring (November).

Based on the marine chemical species indicators, the nitrate peak at $20-40 \mathrm{~cm}$ would correspond to a time period such as late summer to early fall, but the number of potential sources of nitrate to this area precludes any unique identification of a nitrate source. However, a peak in nitrate during the summer has been noted for samples from the Ross Ice Shelf, Antarctica (Herron, 1982[a]). Notably, Aristarain and others (1982) did not find a seasonal signal for nitrate in their studies on James Ross Island.

If the seasonal signal, as defined by the chemical species studied here, is correct, the winter part of the mass balance is approximately $100 \mathrm{~cm}$ snow equivalent and the summer part of the balance is at least $120 \mathrm{~cm}$ snow equivalent. Since our snow pit does not necessarily include a complete cycle, we cannot compute the absolute total mass balance. We favor a larger summer balance than a winter balance simply because of the greater availability of open ocean around Heard Island in the summer season, and hence suggest that we do not have an entire summer.

In conclusion, we suggest that marine-source chemical species, such as chloride, sodium, and sulfate, are useful in identifying seasons in snow pits on Heard Island. Nitrate may also be a useful seasonal indicator, although its source cannot be uniquely specified. Fluoride and bromide signals are random and diffuse, respectively, due probably to the presence of a volcanic source on the island. Iron and probably other particles such as silicate and, by analogy, crustally derived microparticles appear not to be useful seasonal indicators because they are long-travelled and highly filtered by the time they reach Heard Island, and thus provide a relatively constant atmospheric background level throughout the year. We suggest that shallow coring in the higher-elevation areas of Heard Island, where ablation is zero, could provide a detailed record of the mass balance, climate, and atmospheric chemistry history of this island for a time period of at least several tens of years or perhaps even hundreds of years. The unique position of this island would make such a record extremely valuable.

\section{ACKNOWLEDGEMENTS}

Samples used in this study were collected by M. Hendy while he was a member of the 1982 Heard Island expedition. We should like to thank V. Morgan and I. Allison (Glaciology Section, Antarctic Division, Australian Department of Science and Technology, University of Melbourne) for providing the oxygen-isotope value referred to in the text, and S. Knollmeyer and T.M. Cheatham (Department of Earth Sciences, University of New Hampshire) for their help with the chemical analyses.

\section{REFERENCES}

Allison, I.F. 1980. A preliminary investigation of the physical characteristics of the Yashel Glacier, Heard Island. ANARE Scientific Reports, Ser. A(IV). Glaciology. Publication No. 128.

Aristarain, A.J., and others. 1982. Snow chemistry on James Ross Island (Antarctic Peninsula), by A.J. Aristarain, R.J. Delmas, and M. Briat. Journal of Geophysical Research, Vol. 87, No. C13, p. 11004-12.

Berg, W.W., and others. 1984. Brominated organic species in the Arctic atmosphere, by W.W. Berg, L.E. Heidt, W. Pollock, P.D. Sperry, R.J. Cicerone, and E.S. Gladney. Geophysical Research Letters, Vol. 11, No. 5, p. 429-32.

Budd, G.M. 1964. Heard Island Expedition, 1963. Polar Record, Vol. 12, No. 77, p. 193-95.

Budd, G.M. 1970. Heard Island reconnaissance, 1969. Polar Record, Vol. 15, No. 96, p. 335-36.
Budd, G.M., and Stephenson, P.J. 1970. Recent glacier retreat on Heard Island. [Union Géodésique et Géophysique Internationale. Association Internationale d'Hydrologie Scientifique.] [International Council of Scientific Unions. Scientific Committee on Antarctic Research. International Association of Scientific Hydrology. Commission of Snow and Ice.] International Symposium on Antarctic Glaciological Exploration (ISAGE), Hanover, New Hampshire, U.S.A., 3-7 September 1968, p. 449-58. [(Publication No. 86 [de l'Association Internationale d'Hydrologie Scientifique].)]

Budd, W.F., and Allison, I. 1975. An empirical scheme for estimating the dynamics of unmeasured glaciers. [Union Géodésique et Géophysique Internationale. Association Internationale des Sciences Hydrologiques. Commission des Neiges et Glaces.] Symposium. Neiges et Glaces. Actes du colloque de Moscow, août 1971, p. 246-56. (IAHS-AISH Publication No. 104.)

Church, T.M., and others. 1982. The chemistry of western Atlantic precipitation at the mid-Atlantic coast and on Bermuda, by T.M. Church, J.N. Galloway, T.D. Jickels, and A.H. Knap. Journal of Geophysical Research, Vol. 87, No. C13, p. 11013-18.

Duce, R.A., and others. 1965. Iodine, bromine and chlorine in the Hawaiian marine atmosphere, by R.A. Duce, J.W. Winchester, and T.W. van Nahl. Journal of Geophysical Research, Vol. 70, No. 8, p. 1775-99.

Galloway, J.N., and others. 1982. The composition of precipitation in remote areas of the world, oy J.N Galloway, G.E. Likens, W.C. Keene, and J.M. Miller. Journal of Geophysical Research, Vol. 87, No. C11, p. 8771-86.

Harding, D., and Miller, J.M. 1982. The influence on rain chemistry of the Hawaiian volcano Kilauea. Journal of Geophysical Research, Vol. 87, No. C2, p. 1225-30.

Herron, M.M. 1982[a]. Glaciochemical dating techniques. (In Curry, Lloyd A., ed. Nuclear and chemical dating techniques: interpreting the environmental record. Houston, TX, American Chemical Society: 303-18. (ACS Symposium Series No. 176.))

Herron, M.M. 1982[b]. Impurity sources of $\mathrm{F}^{-}, \mathrm{Cl}^{-}, \mathrm{NO}_{3}^{-}$ and $\mathrm{SO}_{4}{ }^{2-}$ in Greenland and Antarctic precipitation. Journal of Geophysical Research, Vol. 87, No. C4, p. 3052-60.

Lambeth, A.J. 1951. Heard Island. Geography and glaciology. Journal and Proceedings of the Royal Society of New South Wales, Vol. 84, p. 92-98.

Lyons, W.B., and Mayewski, P.A. 1983. Nitrate plus nitrite concentrations in a Himalayan ice core. Geophysical Research Letters, Vol. 10, No. 12, p. 1160-63.

Mayewski, P.A., and Lyons, W.B. 1982. Source and climatic implication of the reactive iron and reactive silicate concentration found in a core from Meserve Glacier, Antarctica. Geophysical Research Letters, Vol. 9, No. 3, p. 190-92.

Mayewski, P.A., and others. 1984. Interpretation of the chemical and physical time-series retrieved from Sentik Glacier, Ladakh Himalaya, India, by P.A. Mayewski, W.B. Lyons, N. Ahmad, G. Smith, and M. Pourchet. Journal of Glaciology, Vol. 30, No. 104, p. 66-76.

Radok, U., and Watts, D. 1975. A synoptic background to glacier variations on Heard Island. [Union Géodésique et Géophysique Internationale. Association Internationale des Sciences Hydrologiques. Commission des Neiges et Glaces.] Symposium. Neiges et Glaces. Actes du colloque de Moscow, août 1971, p. 42-56. (IAHS-AISH Publication No. 104.)

Zwally, H.J., and others. 1983. Antarctic sea ice, 1973-1976: satellite passive-microwave observations, by H.J. Zwally, J.C. Comiso, C.L. Parkinson, J. Campbell, F.D. Carsey, and P. Gloersen. Washington, DC, National Aeronautics and Space Administration. Scientific and Technical Information Branch. (NASA SP-459.) 